\title{
POLÍTICAS PÚBLICAS E A TRANSFORMAÇÃO DE ANTIGAS ÁREAS INDUSTRIAIS - O CASO DA CIDADE DE SÃO PAULO
}

\author{
POLÍTICAS PÚBLICAS Y LA TRANSFORMACIÓN DE ANTIGUAS ÁREAS INDUSTRIALES - EL CASO DE \\ LA CIUDAD DE SÃO PAULO
}

\section{PUBLIC POLICIES AND THE TRANSFORMATION OF FORMER INDUSTRIAL AREAS - THE CASE OF THE CITY OF SÃO PAULO}

\section{SEVERINI, VALÉRIA FERRAZ}

Doutora, Arquiteta Urbanista, email: valferraz@yahoo.com

\section{RESUMO}

A configuração espacial das antigas áreas industriais da cidade de São Paulo vem atraindo construtoras e incorporadoras que buscam terrenos amplos e planos para viabilizar a implantação de empreendimentos de grande porte, como condomínios residenciais e shopping centers. Considerados polos geradores de tráfego, esses estabelecimentos sobrecarregam a malha viária e saturam a infraestrutura urbana. Além disso, seus projetos não necessariamente vêm acompanhados de diretrizes urbanísticas capazes de assegurar uma relação harmoniosa entre espaço público e espaço privado, de conservar o patrimônio histórico edificado ou de ajudar a evitar a descontinuidade do sistema viário. Parte-se da premissa que políticas públicas de desenvolvimento urbano são essenciais para qualificar a transformação dessas áreas, em especial o Plano Diretor e a Lei de Zoneamento. Diante disso, esse artigo tem como objetivo principal analisar como as diretrizes de requalificação para as antigas áreas industriais, situadas nas orlas ferroviária e fluvial e previstas no Plano Diretor Estratégico, foram de fato incorporadas na Lei de Parcelamento, Uso e Ocupação do Solo do Município de São Paulo. Utiliza-se como metodologia a análise de dados secundários, tomando por base o material disponível no site "Gestão Urbana", que inclui o texto das respectivas leis, seus mapas e quadros e as cartilhas com as estratégias ilustradas.

PALAVRAS-CHAVE: antigas áreas industriais; políticas públicas; espaço público; planejamento urbano, São Paulo.

\section{RESUMEN}

La configuración espacial de las antiguas áreas industriales de la ciudad de São Paulo viene atrayendo constructoras e incorporadoras que buscan terrenos amplios y planes para viabilizar la implantación de emprendimientos de gran porte, como condominios residenciales y centros comerciales. Considerados por los generadores de tráfico, esos establecimientos sobrecargan la malla vial y saturan la infraestructura urbana. Además, sus proyectos no necesariamente vienen acompañados de directrices urbanísticas capaces de asegurar una relación armoniosa entre espacio público y espacio privado, de conservar el patrimonio histórico edificado o de ayudar a evitar la discontinuidad del sistema viario. Se parte de la premisa que las políticas públicas de desarrollo urbano son esenciales para calificar la transformación de esas áreas, en especial el Plan Director y la Ley de Zonificación. En este sentido, este artículo tiene como objetivo principal analizar cómo las directrices de recalificación para las antiguas áreas industriales, situadas en las orillas ferroviarias y fluviales y previstas en el Plan Director Estratégico, fueron de hecho incorporadas en la Ley de Parcelamiento, Uso y Ocupación del suelo del Municipio de San Pablo. Se utiliza como metodología el análisis de datos secundarios, tomando como base el material disponible en el sitio "Gestão Urbana", que incluye el texto de las respectivas leyes, sus mapas y cuadros y las cartillas con las estrategias ilustradas. PALABRAS CLAVES: antiguas áreas industriales; políticas públicas; espacio público; planificación urbana; ciudad de São Paulo.

\section{ABSTRACT}

The spatial configuration of the former industrial areas of the city of São Paulo has been attracting builders and real estate developers looking for broad plots and plans to make feasible the implementation of large enterprises, such as gated communities and shopping malls. Considered traffic generate poles, these establishments overload the road network and saturate the urban infrastructure. In addition, their respective projects are not necessarily accompanied by urban planning guidelines capable of ensuring a harmonious relationship between public space and private space, to preserve the built heritage or to help prevent discontinuation of the road system. It is based on the premise that public policies for urban development are essential to qualify the transformation of these areas, especially the Master Plan and the Zoning Law. Therefore, this article has as main objective to analyze how the requalification guidelines for the former industrial areas, located in the railroad and fluvial borders and planned in the Strategic Master Plan, were in fact incorporated in the Sao Paulo Zoning Law. It is used as methodology the analysis of secondary data, based on the material available on the "Gestão Urbana" website, which includes the text of the respective laws, their maps and tables and the booklets with the illustrated strategies.

KEYWORDS: former industrial areas; public policies; public space; urban planning; city of Sao Paulo. 


\section{INTRODUÇÃO (PROBLEMÁTICA E JUSTIFICATIVA)}

A cultura cafeeira, difundida em meados do século XIX no interior paulista, foi fator fundamental para a transformação econômica, sociocultural e política da cidade de São Paulo. A instauração de um regime de trabalho assalariado nas fazendas de café atraiu gente do mundo todo ${ }^{1}$. Os imigrantes entravam no país pelo porto de Santos e subiam a serra por meio da estrada de ferro São Paulo Railway. Tendo como destino final a cidade de Jundiaí, a ferrovia tinha uma parada estratégica na Estação da Luz, situada na capital paulista. Muitos imigrantes optaram por ficar em São Paulo pois a cidade estava em plena expansão e necessitava de mão de obra qualificada para trabalhar em outras áreas, como na construção civil e no outro ciclo econômico que se despontava na época: a indústria (REIS FILHO, 2004).

Implementadas nas bordas das várzeas dos rios paulistanos ${ }^{2}$, três ferrovias foram fundamentais nesse processo. A Estrada de Ferro Santos-Jundiaí (São Paulo Railway) foi inaugurada em 1867 e tinha como propósito principal o escoamento da produção de café. Já a ferrovia Central do Brasil, construída em diferentes fases ao longo da segunda metade do século XIX, visava promover a integração dos territórios do Rio de Janeiro, São Paulo e Minas Gerais. Construída em 1870, a Estrada de Ferro Sorocabana promovia o escoamento da produção de algodão e café produzida no oeste paulista (LAMOUNIER, 2012). Atualmente essas ferrovias transportam apenas passageiros e compõe as Linhas 7, 8, 9, 10, 11 e 12 da Companhia Paulista de Trens Metropolitanos (CPTM).

Num primeiro momento, a indústria paulistana, caracterizada principalmente por empresas de médio porte e pequenas oficinas, se fixou junto às estações ferroviárias e próxima aos rios Tietê e Tamanduateí. Face ao baixo preço dos terrenos e a facilidade de transporte dos produtos, bairros como Mooca, Ipiranga, Brás, Bom Retiro, Água Branca e Lapa foram loteados e cresceram rapidamente marcados por um cenário de fabriquetas, casebres, vilas e cortiços. As indústrias surgiram para atender tanto as demandas da produção cafeeira quanto da população que crescia de forma exponencial ${ }^{3}$. Situada no bairro da Mooca, a fábrica de algodão Cotonifício Rodolfo Crespi foi umas das principais indústrias da cidade que realizava desde a limpeza do algodão até a confecção de tecidos e roupas (inclusive produzia as sacas de café). Mas não se tratava apenas de grandes indústrias. Segundo Rolnik (2003, p. 78):

Por volta de 1901, concentravam-se nesses núcleos as indústrias mais expressivas, coexistindo ao lado de um incalculável número de tendas de sapatarias, marcenarias, fábricas de macarrão, graxas, óleos, tintas, fundições, tinturarias, fábricas de calçados, roupas, chapéus, além de ateliês domésticos que produziam alimentos, bebidas e produtos químicos como sabão e velas.

Com o declínio do transporte ferroviário a partir dos anos de 1950 e com a valorização do transporte individual e criação de uma rede de rodovias, há um redirecionamento da expansão das indústrias para além das linhas férreas, ainda dentro do território paulistano. O advento da tecnologia nos anos de 1970 intensificou a crise do modelo de produção fordista e novas práticas industriais foram adotadas. Entre elas: utilização da tecnologia de automação; redução da mão de obra empregada e terceirização das funções, flexibilização das relações de trabalho e ênfase nas áreas de pesquisa, design e marketing. Passa-se a ter uma mistura de usos industriais com outros usos urbanos, estimulando pequenas empresas que se beneficiam da inserção no mercado de consumo metropolitano e das relações com as empresas maiores (BALDONI, 2002).

Todos esses fatores levam a um "espraiamento da indústria" para cidades da Região Metropolitana de São Paulo e muitas instalações industriais situadas na capital tiveram seus usos alterados. Segundo estudo de Sepe \& Silva (apud VALENTIM, 2007), entre 1996 e 2004, "foram identificadas 2070 áreas industriais que sofreram alteração de uso com solicitação de alteração de sua classificação para fins de recolhimento de IPTU". Segundos os autores, parte dessas áreas, cerca de $65 \%$, passou a abrigar atividades comerciais variadas, lojas, armazéns e depósitos. Outra parte significativa, aproximadamente 17\%, teve o uso modificado para fins residenciais.

A nova conformação do modelo industrial paulistano acabou induzindo uma reorganização da cidade, com tendência a substituição do uso e da ocupação do solo nos grandes lotes e glebas. O interesse do mercado imobiliário por essas áreas passa a se tornar evidente já no final do século passado, mas os grandes empreendimentos acabam sendo viabilizados no início desse século. O Shopping Vila Olímpia, localizado nas proximidades da Marginal do Rio Pinheiros, é um exemplo. Inaugurado em 2009, o shopping foi implantado em um terreno de cerca de $30.000 \mathrm{~m}^{2}$, antes ocupado por uma fábrica. Suas fachadas são totalmente vedadas e o empreendimento com apenas duas entradas para pedestres.

Já o empreendimento Luzes da Mooca foi construído no terreno que abrigava a antiga fábrica Açúcar União e é composto por sete edifícios: cinco edifícios residenciais e dois edifícios coorporativos. O empreendimento 
de aproximadamente $35.000 \mathrm{~m}^{2}$, situado nas proximidades da Linha 10 da CPTM, conta com uma espécie de praça pública construída ao redor da chaminé da antiga fábrica (que foi preservada). Contudo, a falta de permeabilidade física e a presença de funcionários que vigiam o local dia e noite, impede a circulação de pedestres (o empreendimento é cercado por três ruas) e inviabiliza a utilização da praça como um verdadeiro espaço público.

Denominados por Caldeira (2000, p. 258) de "enclaves fortificados", esses empreendimentos "enfatizam o valor do que é privado e restrito ao mesmo tempo que desvalorizam o que é público e aberto na cidade". Para a autora (CALDEIRA, 2000), eles vendem a imagem que tudo o que é necessário a vida de um ser humano está sendo providenciado nesses locais, como se a cidade não fosse mais necessária.

A interferência do poder público nos terrenos privados no Brasil é recente. Regulamentadas apenas na Constituição de 1988, por meio dos artigos 182 e 183, as questões relacionadas à terra passaram a seguir normas e diretrizes através da exigência da elaboração de políticas públicas municipais. Contudo, apenas com a regulamentação do Estatuto da Cidade, Lei 10.257/2001, é que uma série de instrumentos urbanísticos passaram a ser inseridos em tais políticas. Entre os princípios básicos do Estatuto, destacam-se a função social da propriedade e o planejamento participativo. Pela primeira vez, admite-se que o bem comum deve prevalecer sobre os interesses privados. Como diretriz nacional, tornou-se fundamental a elaboração de Planos Diretores, que passaram a determinar as estratégias de crescimento da cidade, indicar o perfil econômico e definir as áreas de expansão urbana. Para dar conta de implantar tais diretrizes, os municípios passaram também a elaborar e regulamentar leis municipais complementares, como a Lei de Zoneamento, o Plano Plurianual, Gestão Orçamentária Participativa, Planos e Projetos Setoriais e de Bairro.

Parte-se do princípio que, de todas as leis complementares, a Lei de Zoneamento é a mais efetiva no que tange as intervenções físicas e funcionais no território, pois ela normatiza a ação pública e privada sobre as formas de parcelamento, uso e ocupação do solo. Os instrumentos urbanísticos previstos em cada "zona" indicam, por exemplo, se o tipo de urbanização prevista para as antigas áreas industriais será adensado ou espraiado. É na Lei de Zoneamento também que se determina o tamanho máximo de lotes e quadras, fator determinante para viabilizar ou impossibilitar a implementação de grandes empreendimentos.

As Operações Urbanas Consorciadas (OUC) são outra alternativa para a requalificação urbana de trechos urbanos. Definidas em lei próprias, as OUC contam como Projetos de Intervenção Urbana (PIU) projetados para um determinado perímetro urbano sobre os quais incidem índices e parâmetros urbanísticos adicionais àqueles previstos na Lei de Zoneamento. Fica a cargo do poder público utilizar os recursos obtidos (a partir de contrapartida financeira pela concessão de aumento do coeficiente de aproveitamento ou de alteração de uso) em melhorias urbanísticas e estruturais no perímetro da OUC. Mas os resultados obtidos com as Operações Urbanas Consorciadas vigentes na cidade de São Paulo apontam para a priorização de investimentos visando apenas o crescimento econômico da região, deixando de lado questões de caráter sócio espacial e histórico, tidos como essenciais para a melhoria da qualidade de vida da população. Para Sales (2005), o resultado da Operação Urbana Faria-Lima, por exemplo, expõe "um modelo de desenvolvimento urbano que, em grande medida, concentra e limita as oportunidades a pontos restritos do território, drena os recursos disponíveis e dificulta alternativas urbanísticas".

Esse artigo tem como objetivo central explorar como políticas públicas de desenvolvimento urbano podem contribuir para a requalificação de antigas áreas industriais, em especial o Plano Diretor e a Lei de Zoneamento. Utiliza-se a metodologia de análise de dados secundários que consiste em usar dados préexistentes, já coletados, tabulados e/ou mapeados, condizentes ao objeto de estudo da pesquisa. $O$ levantamento de dados secundários envolve a pesquisa e consulta de levantamentos bibliográficos, documentais e estatísticos. As informações pertinentes passam por um processo de análise tornando possível produzir um novo conhecimento a partir de dados existentes e dispersos. Toma-se como base de estudo as recentes políticas públicas de desenvolvimento urbano da cidade de São Paulo, em especial o Plano Diretor Estratégico - PDE (Lei 16.050/14) e a Lei de Parcelamento, Uso e Ocupação do Solo - LPUOS (Lei 16.402/16). As informações foram obtidas principalmente pelo site Gestão Urbana e pelo Mapa Digital da cidade de São Paulo (GeoSampa). O recorte espacial adotado é o Setor I da Macroárea de Estruturação Metropolitana, definido no PDE como o setor que abrange as áreas próximas às ferrovias e dos rios Tietê, Pinheiros e Tamanduateí.

Inicialmente são apresentadas as estratégias de ordenamento territorial do PDE paulistano, indicando como as antigas áreas industrias foram inseridas nesse contexto. Em seguida são apresentados os três territórios definidos na Lei de Zoneamento da capital paulista (LPUOS) e as características de suas respectivas zonas. Posteriormente, os onze objetivos específicos para o Setor I da Macroárea de Estruturação Metropolitana são analisados sob a ótica do parcelamento, uso e ocupação do solo. 


\section{ANTIGAS ÁREAS INDUSTRIAIS NO PROCESSO DE REESTRUTURAÇÃO DO TERRITÓRIO PAULISTANO}

O Plano Diretor Estratégico (PDE) da cidade de São Paulo (Lei 16.050/14) tem como proposta central reequilibrar os espaços da cidade a fim de conter o processo de urbanização periférica e acomodar o crescimento urbano em áreas centrais e/ou em áreas subutilizadas dotadas de infraestrutura. Essa nova concepção de cidade exigiu uma reestruturação territorial, que foi dividida em "macrozonas e macroáreas". A "Macrozona de estruturação e qualificação urbana" foi definida como a área do Município mais propícia para abrigar os usos e atividades urbanos, e foi dividida em 4 (quatro) macro áreas: (a) Macroárea de estruturação metropolitana; (b) Macroárea de urbanização consolidada; (c) Macroárea de qualificação da urbanização; (d) Macroárea de redução da vulnerabilidade urbana.

Vista como peça chave no processo de reorganização do território paulistano, a "Macroárea de estruturação metropolitana", abrange as regiões da cidade onde se verificam processos de transformação econômica e de padrões de uso e ocupação do solo. Essa macroárea é composta por três setores: (I) Setor Orla Ferroviária e Fluvial; (II) Setor Eixos de Desenvolvimento; (III) Setor Central.

Este trabalho concentra seus esforços no Setor I da Macroárea de Estruturação Metropolitana, uma vez que ele é formado por áreas situadas no entorno das ferrovias e dos rios Tietê, Pinheiros e Tamanduateí, onde existem grandes terrenos ociosos ou subutilizados previamente ocupados por indústrias (ver Figura 1).

Figura 1 - Mapa da Macroárea de Estruturação Metropolitana.

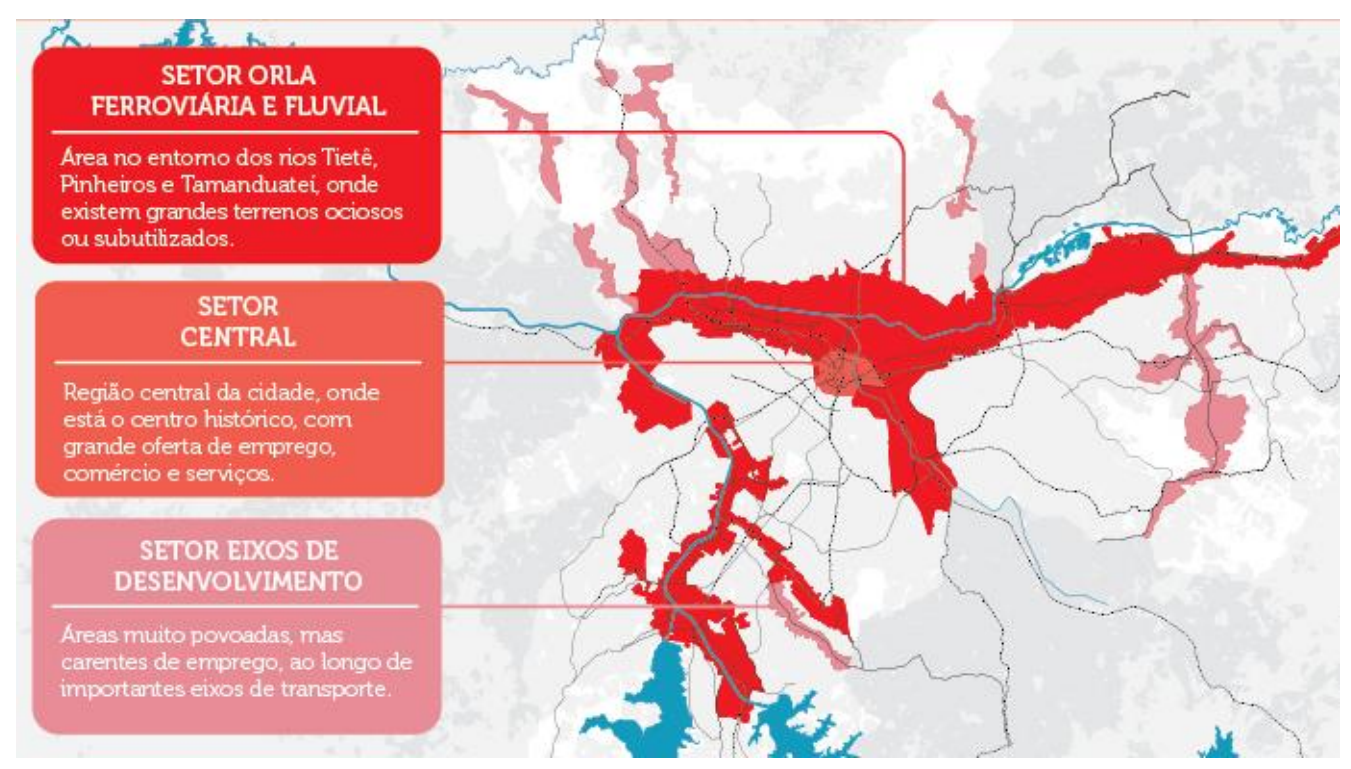

Fonte: Gestão Urbana, Prefeitura Municipal de São Paulo, 2018.

No Artigo 12 do PDE, foram definidos objetivos específicos para cada um desses setores. Este artigo irá tratar apenas os objetivos específicos para o Setor I - Orla Ferroviária e Fluvial.

\section{Lei de Parcelamento, Uso e Ocupação do Solo do Município de São Paulo - LPUOS}

A reestruturação urbana proposta no PDE, exigiu a elaboração de uma nova Lei de Zoneamento. Regulamentada em 2016, a Lei de Parcelamento, Uso e Ocupação do Solo do Município de São Paulo LPUOS (Lei 16.402/16), dividiu o território paulistano em: Território de Transformação, Território de Qualificação e Território de Preservação (Figura 2). Para cada um dos territórios estipulou-se um conjunto de zonas. Cada "zona" define uma série de parâmetros urbanísticos ligados ao parcelamento, uso e ocupação do solo. 
Figura 2 - Esquema gráfico dos territórios de transformação, de qualificação e de preservação previstos na LPUOS.

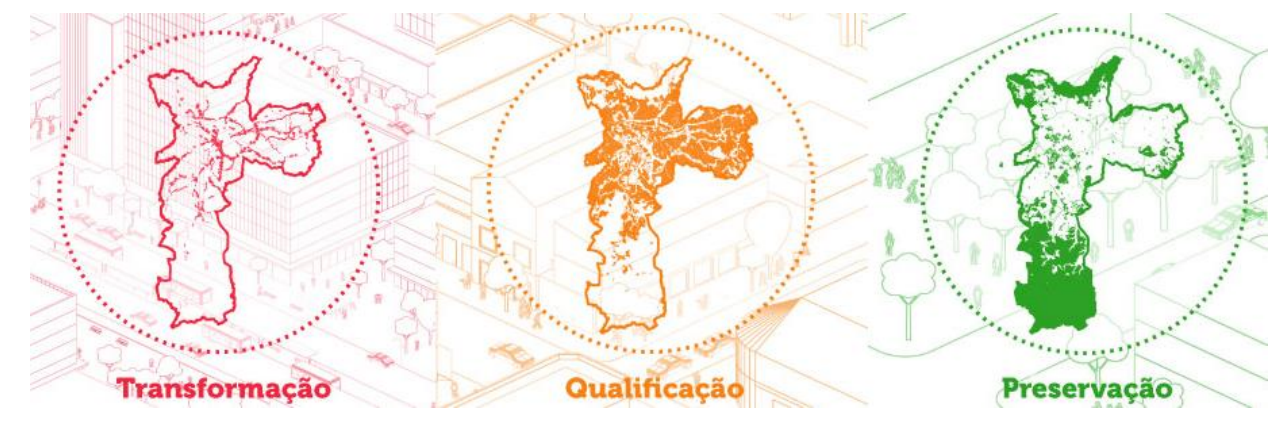

Fonte: Gestão Urbana, Prefeitura Municipal de São Paulo, 2018.

O Território de Transformação é formado pelas Zonas Eixo de Estruturação da Transformação Urbana (ZEU) que tem como objetivo promover o adensamento construtivo e populacional, a diversificação de atividades e a qualificação paisagística dos espaços públicos. As zonas do território de transformação estão presentes junto as grandes avenidas da cidade dotadas de corredores de ônibus ou estações de trem ou metrô. Esse território é o que possui as zonas capazes de gerarem trechos urbanos densos e verticalizados, que se assemelham ao ideal da cidade compacta. Por meio de uma ideia relativamente simples e lógica, a cidade compacta busca intensificar o território através de densidades elevadas e uso de solo diversificado em trechos da cidade dotados de rica infraestrutura urbana, preservando os miolos de quadra (Figura 3). Este modelo de cidade é ideal para o poder público pois contribui para otimizar o uso do espaço urbano e economizar na manutenção da infraestrutura básica urbana, como no sistema de abastecimento de água, na coleta de lixo, na iluminação pública, na segurança, nos sistemas de rede e telefonia e, principalmente, no sistema de transporte público. A cidade compacta traz benefícios também a moradores e turistas, que passam a usufruir a cidade de forma mais intensa e proveitosa (SEVERINI, 2015).

Figura 3 - Esquema gráfico da cidade compacta.

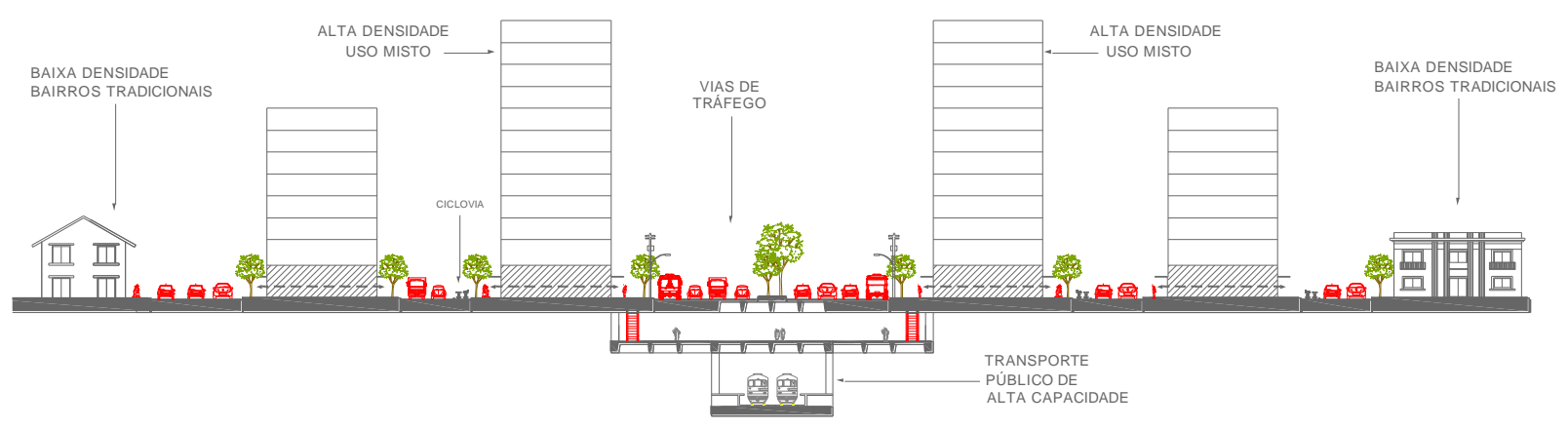

Fonte: Autora, 2018.

As Zonas Eixo de Estruturação da Transformação Urbana (ZEU) foram demarcadas principalmente nos lotes adjacentes à grandes avenidas e eixos viários. No mapa abaixo (Figura 4), é possível verificar as zonas do território da transformação (quadras na cor vinho) ao longo de eixo das avenidas Ibirapuera e Vereador José Diniz. 
Figura 4 - Mapa Digital da Cidade de São Paulo, com as camadas sistema viário e zoneamento ativos. Trecho dos bairros de Moema, Campo Belo e Brooklin - eixo viário da Avenida Ibirapuera.

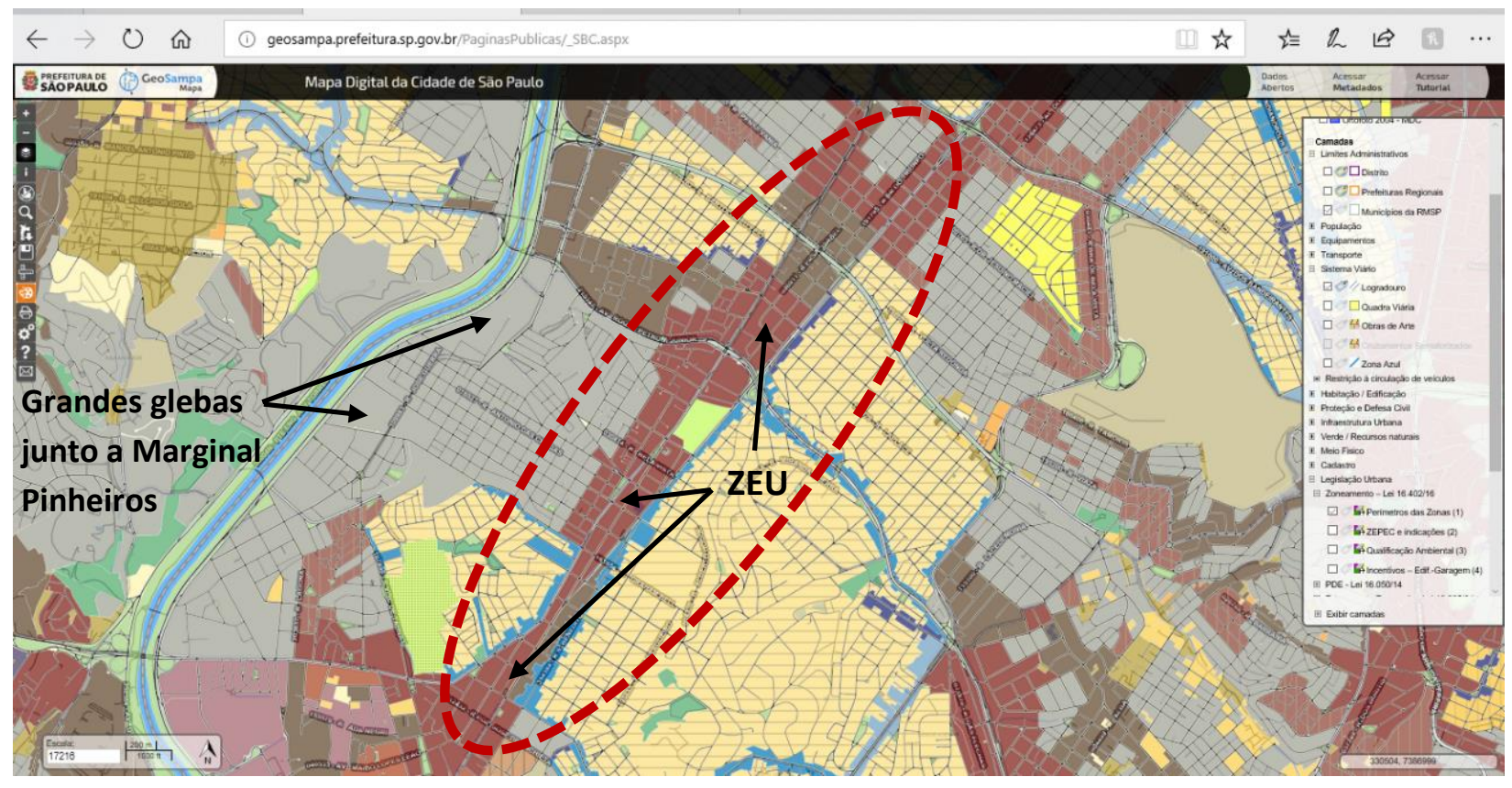

Fonte: GeoSampa, 2018

Por outro lado, o aumento na densidade construtiva e populacional, prevista nas zonas do Território de Transformação exige uma requalificação nos espaços públicos. Como será visto no item a seguir (Item $3-$ Instrumentos Urbanísticos e a Requalificação de Antigas Áreas Industriais), uma série de parâmetros urbanísticos foram criados (e/ou revisados) para garantir bem-estar nas áreas de ZEU. Com destaque para os "parâmetros qualificadores da ocupação", previstos no Artigo 57 da LPUOS.

O Território de Qualificação é formado por uma diversidade de zonas que buscam promover o adensamento populacional moderado, a manutenção de usos não residenciais existentes e o fomento às atividades produtivas. Como é possível verificar no mapa acima (Figura 4), as glebas próximas a Marginal Pinheiros (quadras em cinza), foram demarcadas como Zona Mista (ZM) - porções do território destinadas a promover usos residenciais e não residenciais, com predominância do uso residencial, com densidades construtiva e demográfica baixas e médias. Apesar de ter em seu perímetro "zonas" dos três territórios, o Setor I conta com um número maior de "zonas" do Território de Qualificação.

O Território de Preservação é formado por zonas que buscam promover a preservação de bairros tradicionais e consolidados de baixa e média densidades, de conjuntos urbanos específicos, além de estimular a preservação ambiental e cultural. $\mathrm{O}$ zoneamento do território de preservação abrange as áreas mais vulneráveis do ponto de vista ambiental e urbanístico (zonas em amarelo no mapa acima - Figura 4). A ZEPEC (Zona especial de preservação cultural) é um tipo de zona pertencente ao Território da Preservação que contribui para a manutenção do patrimônio edificado.

\section{INSTRUMENTOS URBANÍSTICOS E A REQUALIFICAÇÃO DE ANTIGAS ÁREAS INDUSTRIAIS}

No parágrafo $1^{\circ}$ do Artigo 12 do PDE paulistano estão definidos os 11 (onze) objetivos específicos a serem alcançados para a requalificação do Setor I da Macroárea de Estruturação Metropolitana. Busca-se investigar como esses objetivos foram de fato incorporados nas três dimensões da Lei de Zoneamento paulistana (parcelamento, uso e ocupação do solo).

I - Transformações estruturais orientadas para o maior aproveitamento da terra urbana com o aumento nas densidades construtiva e demográfica e implantação de novas atividades econômicas de abrangência metropolitana, atendendo a critérios de sustentabilidade e garantindo proteção do patrimônio arquitetônico e cultural, em especial o ferroviário e o industrial; 
O objetivo de gerar "maior aproveitamento da terra urbana", tanto no sentido do adensamento construtivo quanto do demográfico, pode ser identificado no Artigo 55 da LPUOS que trata da ocupação do solo. Foram definidos sete "parâmetros de ocupação do solo"4. Quatro deles estão diretamente ligados ao tipo de adensamento desejado para um trecho urbano. São eles:

- Coeficiente de Aproveitamento (CA): define a quantidade máxima e mínima de metros quadrados que podem ser construídos no lote, somando a área de todos os pavimentos;

- Taxa de Ocupação (TO): define a relação percentual entre a projeção da edificação e a área total do lote;

- Gabarito de altura máxima (GAB): determina a altura máxima da edificação, em metros ou em número de pavimentos;

- Recuos Mínimos (REC): sendo eles frontal, laterais e de fundo, definem as áreas não edificantes do lote.

Quanto maior for o CA, o TO e o GAB de uma determinada zona, mais adensada construtivamente ela será. O PDE definiu CA básico de 1 para toda a zona urbana da cidade de São Paulo. Já o CA máximo depende do tipo de zona em que o terreno está inserido. As zonas integrantes do Território de Transformação, por exemplo, possuem CA de 4, TO de 0,75 e Gabarito sem limite (é possível checar esses valores no Quadro $3^{5}$ da LPUOS). Aqui há uma clara intenção de adensamento construtivo. Em algumas situações específicas, até o recuo frontal é liberado (dados definidos também no Quadro 3).

Já as zonas integrantes do Território de Qualificação, como por exemplo a ZM (zona mista) e a ZPI (zona predominantemente industrial), possuem valores para os parâmetros acima citados inferiores aos da ZEU. $O$ CA máximo nessas zonas é de 2 e 1,5 respectivamente, e o GAB máximo é de 28 metros de altura. A exceção é a ZEIS-3 (zona especial de interesse social), que possui CA de 4 e Gabarito sem limite (a ZEIS está presente nos três territórios).

O mapa abaixo (Figura 5) mostra um fragmento do Setor I da Macroárea de Estruturação Metropolitana, onde é possível verificar as zonas acima citadas. Trata-se de um trecho do bairro Vila Leopoldina, zona oeste de São Paulo, próximo à Marginal Pinheiros e as Linhas 8 e 9 da CPTM. Os lotes adjacentes à Av. Dr. Gastão Vidigal possuem um zoneamento que incentiva a transformação, definidos por meio das Zonas Eixo de Estruturação da Transformação Urbana (ZEU - quadras em laranja listrado e marrom avermelhado) e das Zonas Especiais de Interesse Social (ZEIS - quadras em amarelo). Já os terrenos maiores têm um zoneamento mais moderado definido por meio das Zonas Predominante Industrial (ZPI - quadras em roxo) e Zonas Mistas (ZM - quadras em cinza).

Figura 5 - Mapa Digital da Cidade de São Paulo, com as camadas sistema viário e zoneamento ativos. Trecho do bairro Vila Leopoldina, próxima ao entroncamento entre marginais Pinheiros e Tietê.

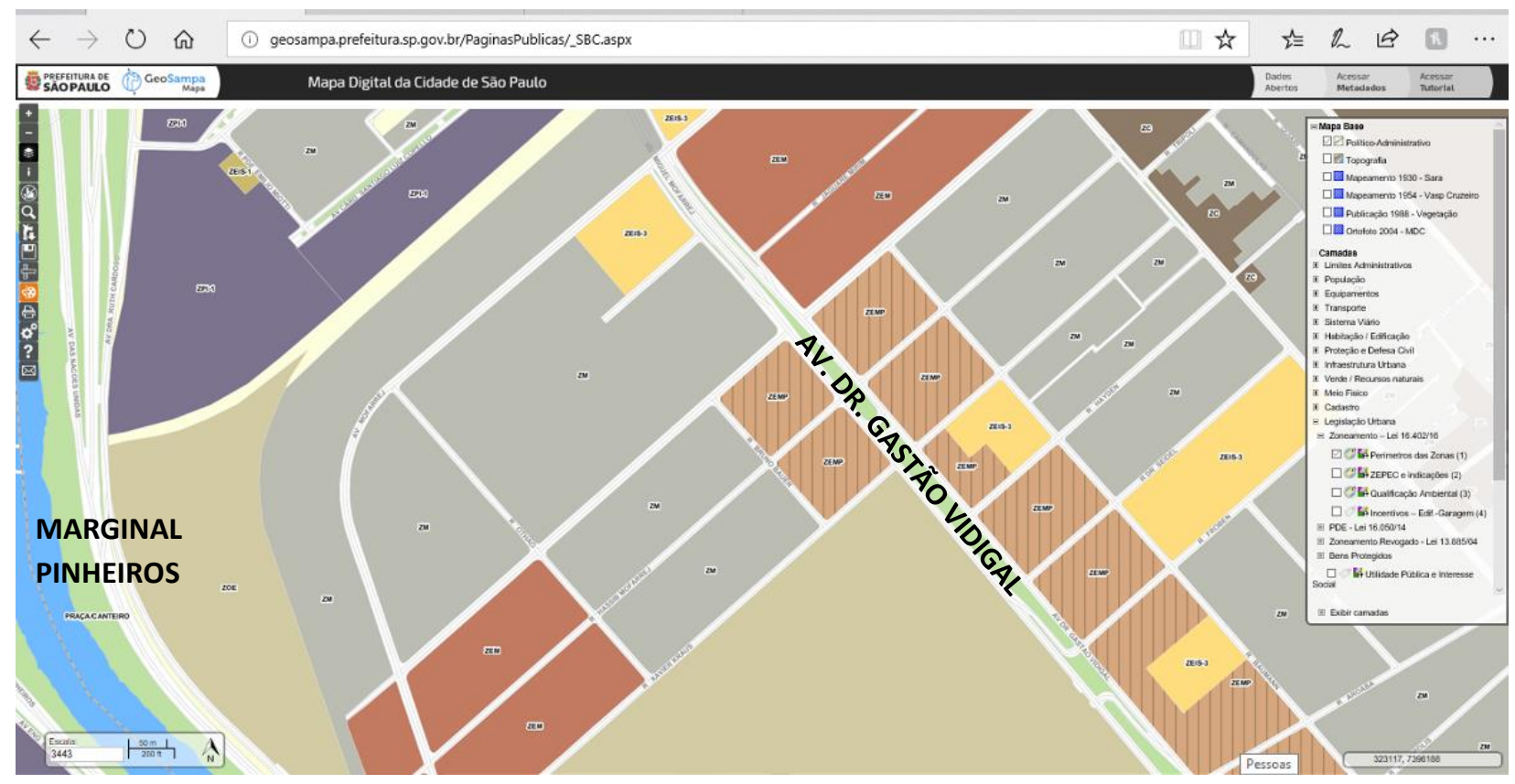

Fonte: GeoSampa, 2018.

Contudo, o aumento no valor desses parâmetros urbanísticos não necessariamente implica num adensamento populacional. Isso porque esses parâmetros não definem a metragem ou especificam um 
número mínimo de apartamentos/conjuntos por andar. Tanto é, que é possível encontrar bairros verticalizados em São Paulo com uma baixa densidade demográfica, como os bairros de Moema e Campo Belo. Ou seja, são bairros de classe média alta que possuem unidades habitacionais de alta metragem quadrada. Isso reforça a ideia de que verticalização não necessariamente traz adensamento populacional (ACIOLY, 1998).

A LPUOS introduziu um novo parâmetro de ocupação do solo, a CAT: Cota-Parte Máxima de Terreno por Unidade. Tido como uma inovação, a Cota-Parte Máxima de Terreno por Unidade defini um número mínimo de unidades habitacionais. A ideia é que haja uma diversidade no tamanho das unidades nos novos edifícios estimulando ocupações urbanas que atendam diferentes faixas de renda e maior adensamento populacional. Esse parâmetro urbanístico só se aplica nas zonas do Território de Transformação e seus valores estão definidos no Quadro 3 da Lei.

As grandes glebas, inseridas no Setor I da Macroárea de Estruturação Metropolitana, contam com uma diversidade de zonas. Isso pode dar suporte ao objetivo de "implantação de novas atividades econômicas". São elas: ZOE (zona de ocupação espacial), ZPI (zona predominantemente industrial), ZDE (zona de desenvolvimento econômico), ZEIS (zona especial de interesse social), ZM (zona mista), ZCOR (zona corredor), ZC (zona centralidade) e ZEPEC (zona especial de preservação cultural). Sendo a última zona, importante o objetivo de garantir "proteção do patrimônio arquitetônico e cultural, em especial o ferroviário e o industrial". Todas as zonas do Município estão definidas no Artigo 6 da LPUOS.

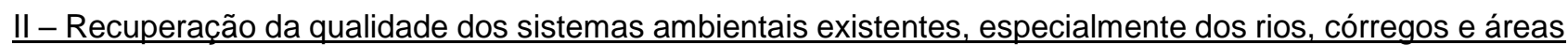
vegetadas, articulando-os adequadamente com os sistemas urbanos, principalmente de drenagem, saneamento básico e mobilidade, com especial atenção à recuperação das planícies fluviais e mitigação das ilhas de calor;

Parte-se do princípio que boa parte da responsabilidade sobre as diretrizes acima citadas é do poder público. A construção de novas estações de tratamento de água e de esgoto, a instalação de biovaletas junto as calçadas, a implementação de arborização viária, assim como a manutenção de bueiros e bocas de lobo são exemplos de ações que devem ser executadas pelo Município. Cabe a iniciativa privada e a sociedade civil algumas ações. A primeira delas é cuidar das benfeitorias ofertadas poder público. Pode parecer óbvio, mas a população não pode jogar lixo nas ruas e nos rios, deve ajudar na manutenção das árvores e calçadas, precisa seguir as regras urbanísticas para não tonar o solo impermeável, entre outras obrigações.

No que tange as regras urbanísticas que podem contribuir para atender esse objetivo, destaca-se aqui a criação de um novo "parâmetro de ocupação do solo": a Quota Ambiental (Figura 6). Previsto no Artigo 55 da LPUOS esse parâmetro estipula um conjunto de regras de ocupação para aumentar a drenagem do terreno e cooperar para reduzir as ilhas de calor. A ideia é incentivar, por exemplo, a construção de telhados verdes, floreiras e jardins permeáveis e construção de reservatório de águas pluviais dentro do lote. Ao utilizar algumas das opções da Quota Ambiental, o proprietário do imóvel consegue benefícios financeiros ou tributários.

Figura 6 - Esquema de Quota Ambiental.

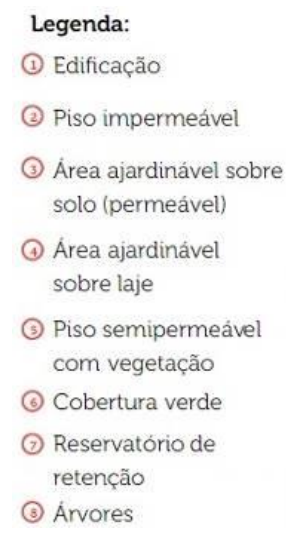

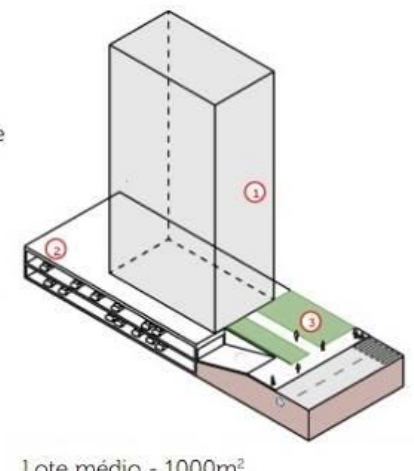

Lote médio $-1000 \mathrm{~m}^{2}$

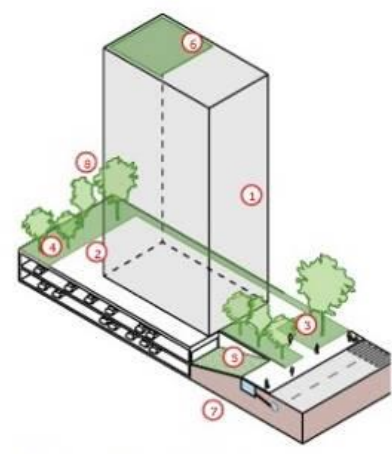

Lote médio $-1000 \mathrm{~m}^{2}$

Fonte: Gestão Urbana, Prefeitura Municipal de São Paulo, 2018. 
III - Manutenção da população moradora, inclusive através da promocão da urbanização e regularização fundiária de assentamentos precários e irregulares ocupados pela população de baixa renda com oferta adequada de serviços, equipamentos e infraestruturas urbanas;

As ZEIS (zonas especiais de interesse social) são um tipo de zoneamento dentro do qual se aplicam regras especiais de uso e ocupação do solo em áreas já ocupadas ou que venham a ser ocupadas por população de baixa renda. Isso é uma espécie de garantia do direito constitucional à moradia, previsto no Artigo 6 da Constituição Federal Brasileira. No PDE paulistano atual estão previstos 5 (cinco) tipos de ZEIS ${ }^{6}$, sendo que três tipos preveem maior adensamento construtivo (ZEIS 2, 3 e 5) do que no PDE anterior.

Conforme mencionado no primeiro objetivo específico, as ZEIS possuem certos parâmetros de ocupação do solo que se assemelham às zonas pertencentes ao Território de Transformação, ou seja, territórios destinados ao adensamento construtivo e populacional. Entre eles, destaca-se o CA de 4, o TO de 0,85 e o Gabarito sem limite para ZEIS 2 e ZEIS 5. Ao que tudo indica, isso pode estimular a implantação de empreendimentos de interesse social por parte da iniciativa privada, contribuindo para a permanência da população moradora. Vale lembrar que apenas a ZEIS-1 é a zona na qual a promoção de melhorias nas áreas demarcadas, através da criação de um plano de urbanização, deve ser feita exclusivamente pelo poder público. Nos outros tipos de ZEIS, a transformação ocorre do mesmo modo que ocorre nas demais zonas. Isto é, são os agentes privados que tomam a iniciativa de comprar o terreno e promover os projetos de melhorias de acordo com as regras definidas para o zoneamento em questão.

Figura 7 - Mapa Digital da Cidade de São Paulo, com as camadas sistema viário e zoneamento ativos. Trecho entre os bairros Mooca e Ipiranga, próxima as avenidas do Estado e Professor Luiz de Anhaia Melo.

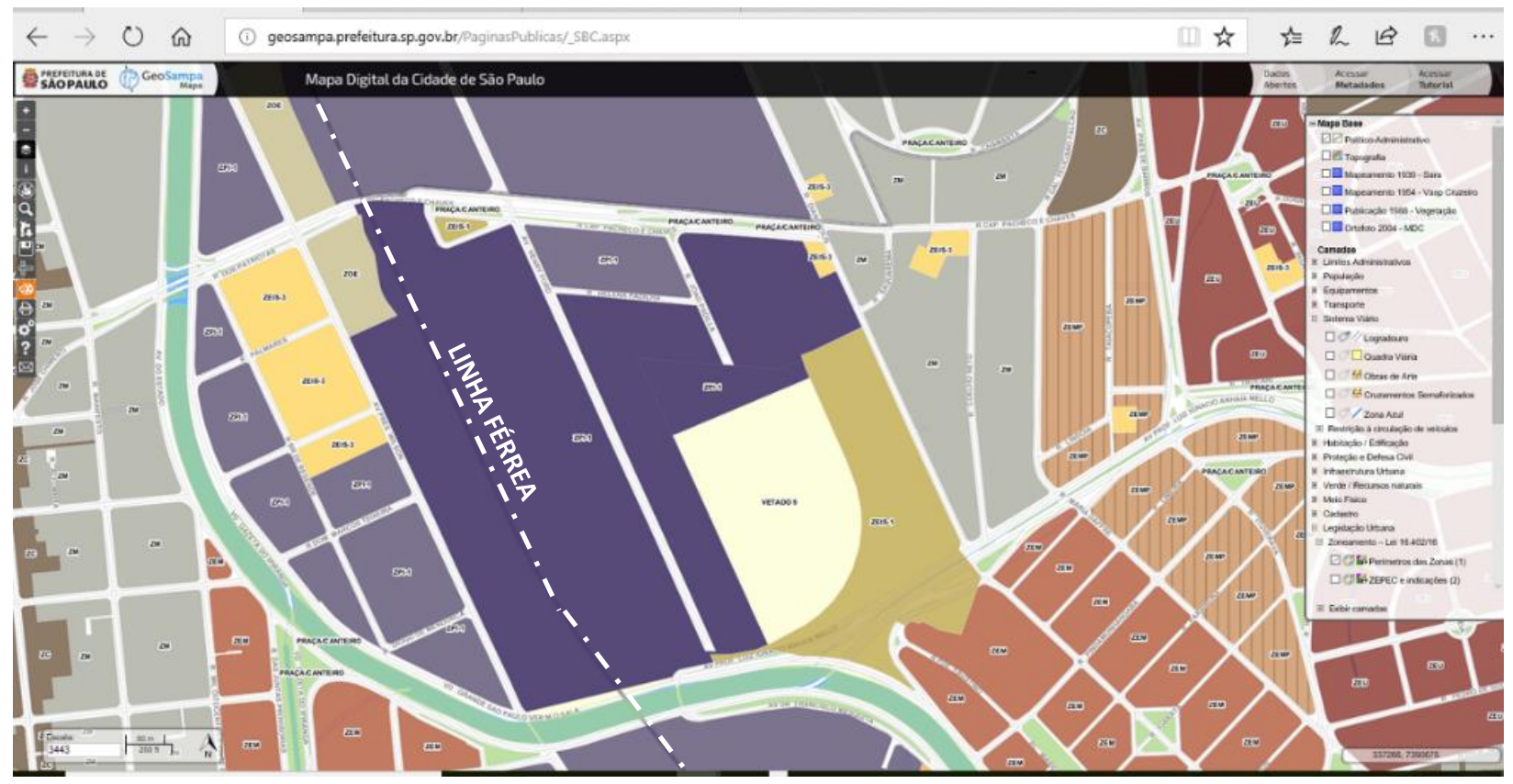

Fonte: GeoSampa, 2018.

No mapa acima (Figura 7) é possível verificar a presença de ZEIS em antigas áreas industriais. Trata-se de um trecho do bairro da Mooca, próximo a Avenida do Estado e a Linha 10 da CPTM. A presença de ZPI (quadras em tons de azul) é notória, assim como a de ZEIS 1 e 3 (quadras em amarelo). Destaca-se também a presença de terrenos demarcados como ZM (zona mista - em cinza), que preveem usos diversos atendendo a demanda de oferta de serviços e equipamentos. As ZEIS permitem também usos diversificados, o que reforça a diretriz em questão.

\section{IV - Produção de HIS e HMP;}

A demarcação das ZEIS é o primeiro passo para estimular a produção de HIS (Habitação de Interesse Social) e HMP (Habitação Mercado Popular). Houve um aumento significativo (cerca de 20\%) na demarcação de áreas de ZEIS no PDE atual em relação ao PDE antigo (Lei 13.885/2004). Contudo, o desafio ainda é grande. Isso porque ainda há a dificuldade de permanência das famílias que, muitas vezes, não se adaptam (ou não 
conseguem se manter no local) e se veem pressionadas em vender seus imóveis seguindo para espaços periféricos, mais baratos, reforçando o velho modelo centro-periferia (SANTORO \& BORRELLI, 2015).

A elaboração de uma política habitacional inclusiva é uma forma alternativa de incentivar a produção de HIS. E isso foi elaborado no PDE paulistano através da "cota da solidariedade" (Artigos 111 e 112). A ideia inicial era fazer com que, a cada novo grande empreendimento (maior que $10.000 \mathrm{~m}^{2}$ ) licenciado, fossem produzidas habitações de interesse social no próprio local (correspondente a $10 \%$ da área construída total do empreendimento) para famílias com renda até três salários mínimos ou que fossem doados terrenos e recursos para o poder público executar essa tarefa. Como contrapartida, esses $10 \%$ não seriam considerados área computável. Contudo, após os debates realizados na Câmara dos Vereadores, alguns itens foram alterados, como a metragem do empreendimento (passou para $20.000 \mathrm{~m}^{2}$ ), a renda das famílias (passou para até 6 salários mínimos) e a necessidade de se construir no mesmo local (agora pode ser construído em qualquer outro lugar da cidade a ser decidido pelo poder público). O Artigo 62 da LPUOS, item XII, regulamenta a área destinada às HIS, provenientes da aplicação da cota da solidariedade, como áreas não computáveis.

$\underline{\mathrm{V} \text { - Incremento e qualificação da oferta de diferentes sistemas de transporte coletivo, articulando-os aos }}$ modos não motorizados de transporte e promovendo melhorias na qualidade urbana e ambiental do entorno;

As áreas que compreendem o Setor I da Macroárea de Estruturação Metropolitana surgiram em função do transporte. Num primeiro momento, as antigas áreas industriais se beneficiaram das linhas férreas e, posteriormente, das vias de tráfego. Sem entrar no mérito da eficiência desses meios de transporte, o cenário que se apresenta é de um sistema de transporte individual e coletivo de alta capacidade. As marginais Pinheiros e Tietê são consideradas as vias expressas mais importantes de cidade. Por meio delas é possível acessar as principais rodovias do Estado e as estradas que ligam São Paulo ao resto do país. A Linha 9 (Esmeralda) da CPTM tangencia praticamente toda a Marginal Pinheiros e, através de algumas estações, se conecta com duas linhas do Metrô. Já a Avenida do Estado (adjacente ao Rio Tamanduateí na regiões central e sudeste) é considerada uma via estrutural importante com capacidade para escoar um fluxo alto de veículos e para fazer a conexão de diversas regiões da cidade. A Av. do Estado conta com o Expresso Tiradentes um sistema de transporte de média capacidade onde circulam ônibus em uma via elevada segregada. Em algumas paradas do Expresso Tiradentes é possível fazer conexão com linhas do Metrô e do Monotrilho.

Mas isso não é tudo. A mobilidade urbana deve priorizar condições de conforto e qualidade relacionadas às calçadas e sua interação com os demais meios de transporte. No Artigo 39 da LPUOS são definidos os "parâmetros de parcelamento do solo". Dentre eles estão a largura mínima de canteiro central, passeio público, via de pedestre, ciclovia e leito carroçável. No Quadro $2 \mathrm{~B}^{7}$ da Lei ficam definidas as larguras mínimas para cada um dos parâmetros acima citados. A calçada, por exemplo, deve ter uma largura mínima de 5 (cinco) metros nas vias estruturais.

Há outra forma de incentivar a construção de calçadas mais confortáveis. Trata-se do "parâmetro qualificador da ocupação": destinação de área para alargamento do passeio público. Previsto no Artigo 57 da LPUOS, esse parâmetro estimula a doação de parte da propriedade privada para o passeio público. Ao doar parte do terreno para o alargamento da calçada, o proprietário poderá contar com certas contrapartidas, como construir mais andares. Há ainda a possibilidade de eliminação da exigência do recuo frontal na hipótese de haver doação de área para alargamento da calçada. De acordo com o Artigo 67, o recuo frontal será facultativo nas zonas tipo ZEU, ZC, ZM e ZEIS desde que a calçada tenha largura mínima de 5 metros.

Nas Zonas Eixo de Estruturação da Transformação Urbana (ZEU) o alargamento da calçada é obrigatório. Já nas zonas do Território de Qualificação, como ZC e ZM, a obrigatoriedade se aplica para lotes maiores que $2.500 \mathrm{~m}^{2}$. Nas Zonas Especiais de Interesse Social e nas Zonas Mistas, o alargamento da calçada é optativo.

Uma outra forma de contribuir com a mobilidade urbana das grandes glebas é através da criação de mais permeabilidade física entre quadras. No Artigo 43 da LPUOS está prevista a área máxima de quadra de $20.000 \mathrm{~m}^{2}$ (vinte mil metros quadrados) e o comprimento máximo da fachada de $300 \mathrm{~m}$ (trezentos metros). A determinação de dimensões máximas de lotes e quadras pode ajudar a evitar a descontinuidade do sistema viário. A estrutura da malha urbana, segundo Hillier (1996) é um fator fundamental de estímulo ao movimento em uma cidade, aumentando a sua conectividade. Opinião compartilhada por Jacobs (2000), que defendia bairros com ruas bem conectadas e quadras curtas.

VI - Regulação da produção imobiliária para captura, pela municipalidade, da valorização imobiliária decorrente de investimentos públicos, para financiamento de melhorias e benefícios públicos: 
O PDE instituiu o FUNDURB - Fundo de Desenvolvimento Urbano com a finalidade de debater, junto com representantes do poder público e da sociedade civil, o destino dos recursos arrecadados com a outorga onerosa. Entre as opões do que se pode fazer com o dinheiro arrecadado está a "aquisição de edifícios ou desapropriação de terrenos para implantação de HIS" e "regularização fundiária".

Vale mencionar que as Operações Urbanas Consorciadas adquirem recursos através das CEPACs, e não por meio de outorga onerosa. Nesse sentido, cada OUC tem uma forma de administrar seus recursos. Na Operação Urbana Consorciada Bairros do Tamanduateí - OUC-BT (Lei 723/2015), por exemplo, foi autorizado pelo poder executivo a constituição de pessoa jurídica, sob a forma de sociedade anônima de economia mista, denominada BTSA, para implementar os Projetos de Intervenção Urbana (PIU). Cabe a essa empresa realizar as ações necessárias para o desenvolvimento e implantação dos projetos e obras, o que inclui a criação de um "banco de terras" ou de "patrimônio imobiliário". A ideia é viabilizar a produção de equipamentos públicos e de habitações de interesse social (HIS), em parceria com a Administração Direta ou Indireta, associandose a utilização dos recursos advindos da comercialização das CEPACs com os do FUNDURB.

VII - Redefinição dos parâmetros de uso e ocupação do solo para qualificação dos espaços públicos e da paisagem urbana;

Além dos tradicionais "parâmetros de ocupação do solo" (mencionados no primeiro objetivo específico), a LPUOS elaborou os "parâmetros qualificadores da ocupação". Previstos no Artigo 57 da Lei, esses parâmetros visam melhorar a relação entre espaço público e espaço privado. São eles: fruição pública, fachada ativa, limite de vedação do lote e destinação de área para alargamento do passeio público. Sendo que o último parâmetro citado já foi mencionado no objetivo $V$ desse artigo.

O "parâmetro qualificador da ocupação" fruição pública procura incentivar uma maior circulação de pedestres e ciclistas por entre as quadras. Pode ser aplicado em novos edifícios a fim de garantir permeabilidade física no pavimento térreo e gerar mais movimento de pessoas. No Artigo 70, a LPUOS estabelece que a fruição pública:

\footnotetext{
I - não poderá ser fechada à circulação de pedestres por nenhum objeto de vedação, temporário ou permanente, podendo ter controle de acesso no período noturno;

II - deverá ter largura mínima de $4 \mathrm{~m}$ (quatro metros), tratamento paisagístico que atenda às normas técnicas pertinentes à acessibilidade universal e, nas áreas de circulação de público, adotar o mesmo tipo de pavimentação da calçada diante do lote.
}

Já no Artigo 87 fica determinado que, nas quadras das zonas integrantes do Território de Transformação (ZEU) e nas ZC (zona centralidade) com áreas entre $10.000 \mathrm{~m}^{2}$ e $20.000 \mathrm{~m}^{2}$ e com uso não residencial o recurso da fruição pública, é obrigatório e deverá ter $20 \%$ da área do lote sem edificação. Já em terrenos menores, com até $10.000 \mathrm{~m}^{2}$, o Artigo 88 da Lei determina que não será cobrado outorga (correspondente a metade do potencial construtivo adicional previsto para área destinada a fruição pública), desde que a área destinada a fruição pública tenha no mínimo $250 \mathrm{~m}^{2}$ e esteja localizada no alinhamento da via ao nível do passeio público, fique aberta permanentemente para a circulação de pedestres e que a área seja averbada em Cartório de Registro de Imóveis.

Figura 8 - Esquema gráfico do parâmetro qualificador da ocupação "fruição pública".

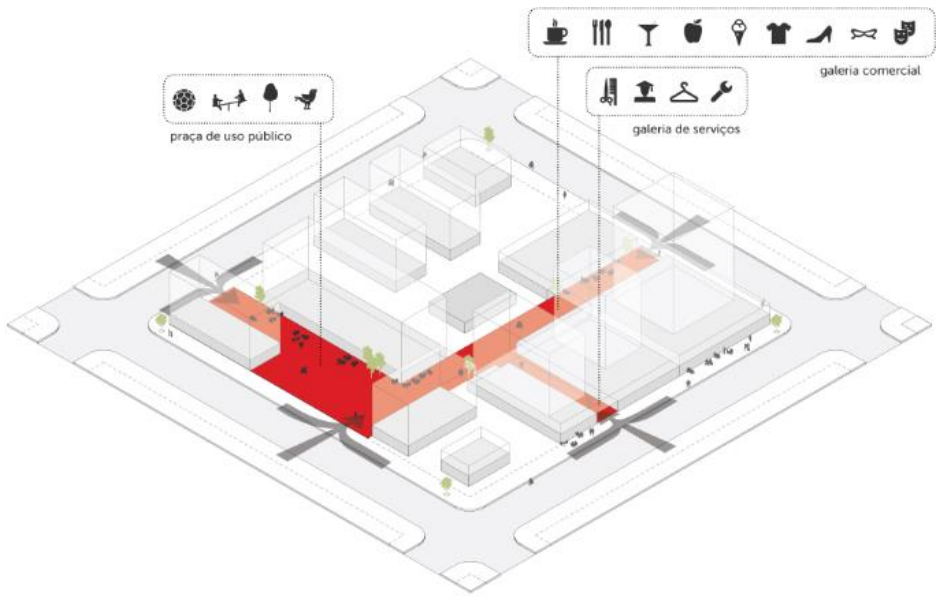

Fonte: Gestão Urbana, Prefeitura Municipal de São Paulo, 2018. 
No entanto, é importante destacar que as motivações para o deslocamento devem estar presentes. Ou seja, polos de geração e atração de fluxos respondem pela intensidade do movimento gerado. Sem estes polos as pessoas tendem a não se deslocar. Daí a importância do seguinte parâmetro, a fachada ativa. Esse "parâmetro qualificador da ocupação", previsto no Artigo 71 da Lei, está relacionado ao estímulo de implantação de atividades comerciais ou de serviços no pavimento térreo de edifícios multifuncionais. A fachada ativa deve ser utilizada em edifícios de uso não residencial e deve:

\footnotetext{
I - estar contida na faixa de $5 \mathrm{~m}$ (cinco metros) a partir do alinhamento do lote, medida em projeção ortogonal da extensão horizontal;

II - ter aberturas para o logradouro público, tais como portas, janelas e vitrines, com permeabilidade visual, com no mínimo 1 (um) acesso direto ao logradouro a cada $20 \mathrm{~m}$ (vinte metros) de testada, a fim de evitar a formação de planos fechados sem permeabilidade visual na interface entre as construções e o logradouro, de modo a dinamizar o passeio público.
}

O Artigo 87 da LPUOS obriga que haja fachada ativa em $25 \%$ da testada do lote de novos em empreendimentos residenciais e não residenciais com áreas entre $10.000 \mathrm{~m}^{2}$ e $20.000 \mathrm{~m}^{2}$, em quadras integrantes das zonas do Território de Transformação (ZEU) e nas ZC (zona centralidade).

Figura 9 - Esquema gráfico do parâmetro qualificador da ocupação "fachada ativa".

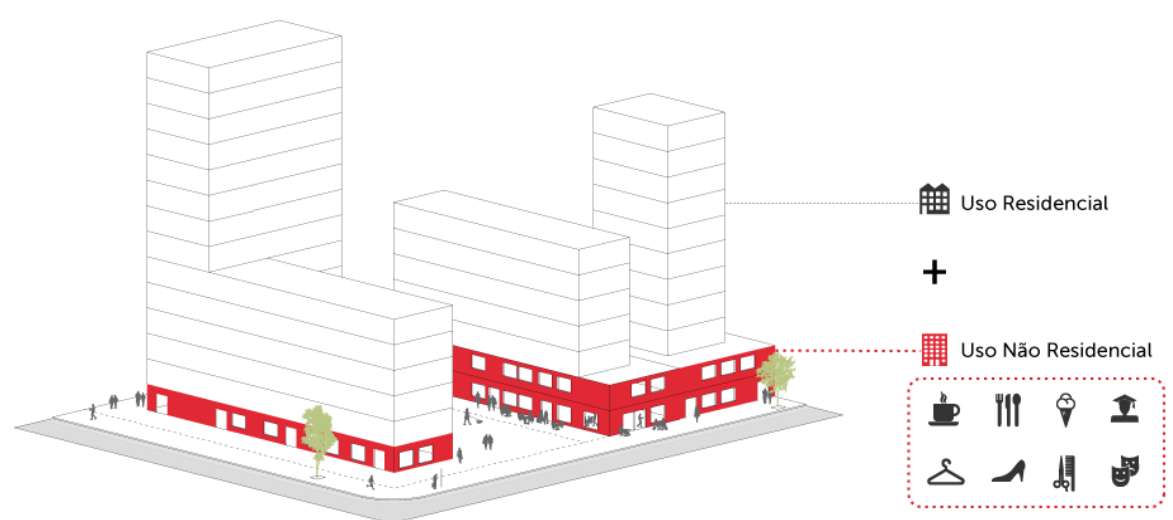

Fonte: Gestão Urbana, Prefeitura Municipal de São Paulo, 2018.

O parâmetro fachada ativa acaba incentivando a utilização de outro parâmetro qualificador da ocupação, o limite de vedação de lote. Isso porque, ao estimular a implantação de atividades que necessitam do espaço público para serem viabilizadas (como as lojas que utilizam vitrines), estimula-se também a instalação de interfaces transparentes e iluminadas para com o espaço público. Esse parâmetro tem como proposta impor limites a extensão de muros ou interfaces opacas que não permitam a visualização do interior do lote. No Artigo 87 fica determinado que, em quadras localizadas nas zonas integrantes do Território de Transformação (ZEU) e nas ZC (zona centralidade) com áreas entre $10.000 \mathrm{~m}^{2}$ e $20.000 \mathrm{~m}^{2}$ e com uso não residencial, apenas $25 \%$ da testada do lote pode ser vedada com muros.

VIII - Minimização dos problemas das áreas com riscos geológico-geotécnicas e de inundação e solos contaminados, acompanhada da prevenção do surgimento de novas situações de vulnerabilidade;

Além do parâmetro quota-ambiental, citado anteriormente, os valores da taxa de permeabilidade mínima (outro parâmetro de ocupação do solo), aumentaram. A taxa de permeabilidade é alta em boa parte dos "perímetros de qualificação ambiental" (PA) presentes no Setor I (ver Quadro 3A) ${ }^{8}$. Em lotes de até $500 \mathrm{~m}^{2}$ a taxa é de 0,15 . Já para lotes acima de $500 \mathrm{~m}^{2}$ a taxa de permeabilidade mínima é de 0,25. Ao levar em consideração que as áreas industriais possuem metragem acima desses valores, há grandes chances de haver uma melhora significativa na retenção e infiltração da água nos lotes e, consequentemente, uma melhora no microclima da região.

Tem-se, por outro lado, um quadro preocupante quanto a questão de solos contaminados. Segundo Valentim (2007), a facilidade de implementação de indústrias em terrenos amplos e planos acarretou na criação de unidades pouco otimizadas em termos espaciais que desfaziam-se dos efluentes, ainda não sujeitos a um controle sanitário e ambiental, nos rios. Como resultado, em bairros como Lapa, Barra Funda, Bom Retiro, 
Brás, Mooca e Ipiranga se manifestaram as primeiras contrariedades ante o desconforto advindo das indústrias, entre eles: a fumaça da chaminé, o barulho do tráfego e do maquinário pesado, o mal cheiro dos corpos d'água já poluídos e os terrenos cobertos por rejeitos da produção (VALENTIM, 2007).

O Artigo 37 (item II) da LPUOS prevê o não parcelamento do solo em "áreas com potencial ou suspeitas de contaminação, em áreas contaminadas e em monitoramento ambiental, sem que haja manifestação favorável do órgão ambiental competente para sua reutilização conforme o uso pretendido". Já o Artigo 137 da Lei condiciona a emissão de alvarás e licenciamentos à manifestação favorável do órgão ambiental competente.

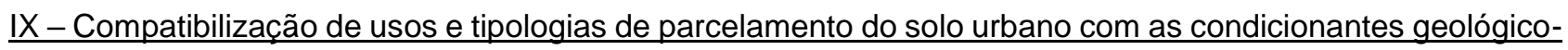
geotécnicas e hidrológicas;

A retificação e poluição dos rios, a implementação de vias de tráfego pesado nas áreas de várzea e a impermeabilização do solo, foram ações que alteraram profundamente as condições naturais das áreas que compõe hoje o Setor I da Macroárea de Estruturação Metropolitana. Essas áreas deveriam fazer parte de um perímetro protegido, destinado a receber as águas dos rios em épocas de cheia. As ações estabelecidas pela LPUOS, como a quota-ambiental e o aumento da taxa de permeabilidade mínima, configuram soluções paliativas e direcionadas à iniciativa privada.

Os Projetos de Intervenção Urbana (PIU), inseridos nos projetos de lei das Operações Urbanas Consorciadas preveem, em certa medida, ações que podem amenizar esse quadro, como a construção de parques lineares e parques urbanos. Porém, a implementação desses projetos está vinculada à venda de CEPACs ${ }^{9}$, trazendo incertezas quanto ao tempo de execução e o custo das obras. Os "piscinões", apesar de não serem a solução ideal do ponto de vista urbanístico, ajudam a controlar as enchentes. Eles atuam como grandes reservatórios de água que retardam a ida das águas para os rios, evitando assim possíveis transbordamentos. A cidade de São Paulo conta com mais de 20 (vinte) "piscinões". O "piscinão" Ipiranga, ainda em construção, está inserido no perímetro do Setor $l$.

$\underline{X}$ - Recuperação, preservação e proteção de imóveis relacionados ao patrimônio industrial e ferroviário, bem como locais de referência da memória operaria, incentivando usos e atividades compatíveis com sua preservação;

As porções do território destinadas à preservação dos bens de valor histórico, arquitetônico e paisagístico, representados por meio de edificações e seus respectivos lotes, sítios urbanos ou arqueológicos, espaços públicos ou elementos paisagísticos, estão demarcadas por meio das Zonas Especiais de Preservação Cultural (ZEPEC). A LPUOS reserva cinco artigos específicos para esse tipo de zoneamento (Artigos 21 até 26).

Essas zonas possuem parâmetros urbanísticos diferenciados que visam garantir não só a preservação do bem material, como também da paisagem urbana ao seu redor. O Artigo 64 da LPUOS, por exemplo, restringe o gabarito a 28 metros de altura na faixa envoltória de vilas residenciais. Não se sabe ao certo as razões pelas quais a LPUOS definiu o valor de 28 metros para o gabarito de altura máxima nos territórios de qualificação e preservação. Para Gehl (2010), a altura ideal de um edifício é de cerca de 15 metros (aproximadamente 5 andares). Segundo o autor (GEHL, 2010), com esse gabarito ainda é possível ver e sentir a cidade (observar as pessoas conversando, se exercitando, passeando, fazendo compras etc.).

No caso das antigas áreas industriais esse valor de 28 metros pode ter uma explicação. Para garantir que as chaminés fossem vistas de vários pontos da cidade (elas têm cerca de 32 metros de altura) e que continuassem atuando como marcos visuais, estabeleceu-se a altura máxima de 28 metros para os novos empreendimentos. Segundo Lynch (1997), os "marcos" caracterizam-se como elementos importantes para a legibilidade do lugar.

No mapa abaixo (Figura 10) é possível conferir as áreas demarcadas como ZEPEC (manchas em vermelho e rosa junto a linha férrea) nas áreas industriais do bairro da Mooca. 
Figura 10 - Mapa Digital da Cidade de São Paulo, com as camadas sistema viário e ZEPECs ativos. Trecho do bairro da Mooca. É possível ver, em vermelho, as ZEPEC junto a ferrovia.

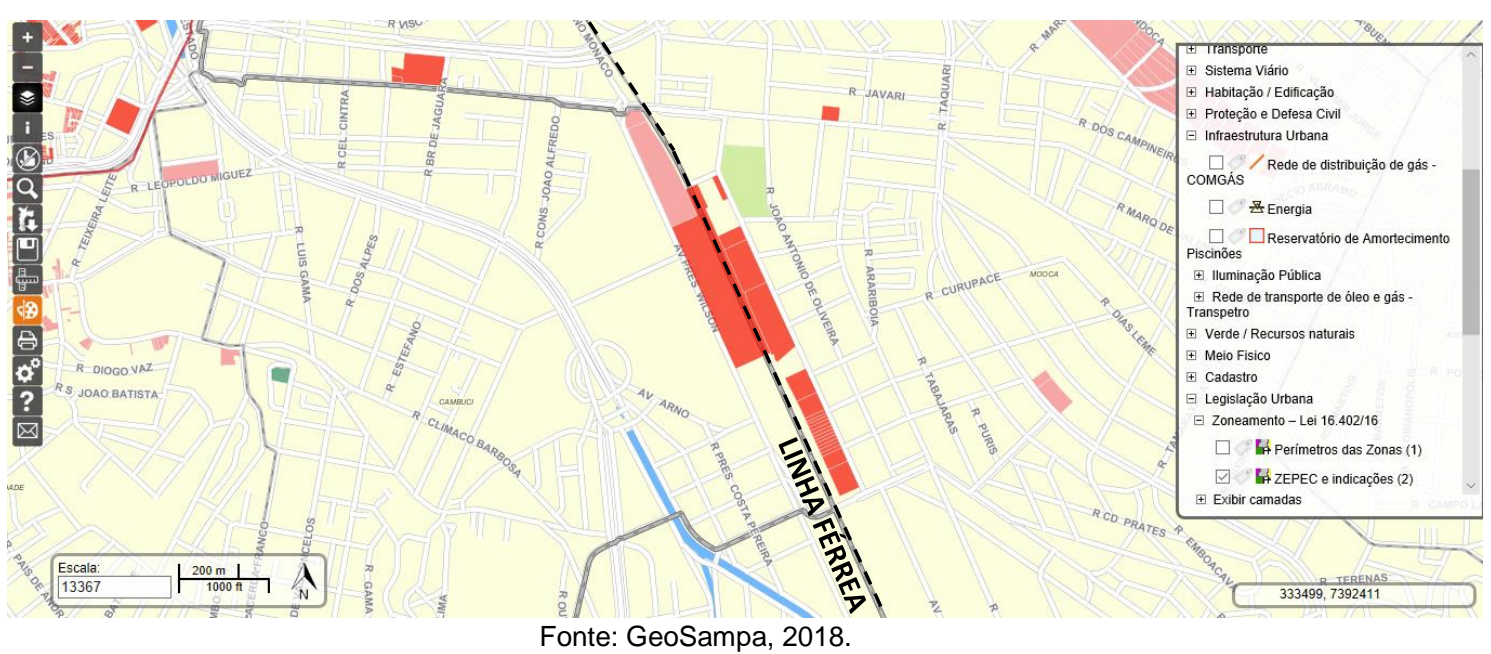

$\underline{X I}$ - Manutenção e estímulo ao emprego industrial e atividades econômicas de abrangência metropolitana;

Uma nova "zona" foi criada na LPUOS que vem ao encontro do objetivo acima descrito. Trata-se da ZED "Zonas de Desenvolvimento Econômico" (Artigo 13 da Lei). Demarcadas em porções do território com a presença de uso industrial, essas zonas são destinadas à manutenção, ao incentivo e à modernização desses usos, às atividades produtivas de alta intensidade em conhecimento e tecnologia e aos centros de pesquisa aplicada e desenvolvimento tecnológico, entre outras atividades econômicas. Trata-se de regiões com perfil econômico específico, como a região do Brás e do Bom Retiro, conhecidas pela fabricação de roupas.

A permanência da ZPI (zona predominantemente industrial) indica que, apesar da restruturação industrial, a atividade se mantém viva. A Zonas Predominantemente Industriais (Artigo 14 da LPUOS) são porções do território destinadas à implantação e manutenção de usos não residenciais diversificados, em especial usos industriais. Já a ZOE (zona de ocupação especial) prevista no Artigo 15 da Lei, são as áreas demarcadas que estão inseridas dentro do perímetro das Operações Urbanas Consorciadas. Elas terão parâmetros específicos de parcelamento, uso e ocupação do solo adequados às suas especificidades e definidos por Projeto de Intervenção Urbana (PIU).

\section{CONSIDERAÇÕES FINAIS}

A reestruturação da indústria nas últimas décadas propiciou uma mobilidade na cadeia produtiva gerando novas possibilidades de uso e ocupação nos lotes industrias. Contudo, as transformações urbanas decorrentes desse processo não vêm ajudando a requalificar as cidades cujas aglomerações industriais estiveram historicamente entrelaçadas ao tecido urbano, como é o caso de São Paulo.

A criação do Setor I da Macroárea de Estruturação Metropolitana foi um passo importante para a requalificação urbana das antigas áreas industriais da cidade de São Paulo. A concepção de "perímetros" (ou "setores") ajudou na identificação de territórios com características e aspectos semelhantes e contribuiu para a preparação de estratégias diferenciadas de planejamento urbano. Ao criar 11 (onze) objetivos específicos a serem alcançados no Setor I, o Plano Diretor Estratégico direcionou as ações que devem ser aprimoradas e regulamentadas nas leis complementares. Este artigo se concentrou na Lei de Zoneamento e, em que medida, as regras de parcelamento, uso e ocupação do solo foram capazes de viabilizar os 11 (onze) objetivos específicos.

A distinção de três tipos de território facilitou a demarcação das zonas e possibilitou uma melhor compreensão do ideal de cidade proposto no PDE. O delineamento do Setor I em boa parte do Território de Qualificação indicou um desejo de transformação mais ameno e de qualidade para as antigas áreas industriais. Boa parte dos parâmetros de ocupação do solo das zonas pertencentes a esse tipo de território incentivam transformações mais moderadas, como CA de 2 e gabarito máximo de 28 metros de altura. A regulamentação da "transferência do potencial construtivo" reforça o desejo de uma mudança mais branda. Ainda assim, são transformações significativas em regiões que sempre se configuraram como horizontais e de baixa densidade populacional. Espera-se que, com a criação dos "parâmetros qualificadores da ocupação", essa qualificação 
aconteça de fato contribuindo para a geração de bem-estar e sensação de acolhimento junto aos espaços públicos das antigas áreas industriais.

\section{REFERÊNCIAS}

ACIOLY, C. Densidade urbana: um instrumento de planejamento e gestão urbana. Rio de Janeiro: Mauad, 1998.

BALDONI, M.A. O lugar da indústria na cidade de São Paulo. Dissertação de Mestrado - Faculdade de Arquitetura e Urbanismo, Universidade de São Paulo, 2002.

CALDEIRA, T. P. Cidade dos muros: crime, segregação e cidadania em São Paulo. São Paulo: Edusp, 2000.

GEHL, J. Cities for People. Washington, DC: Island Press, 2010.

HILLIER, B. Cities as movement economies. In Space is the machine. Cambridge University Press, 1996.

JACOBS, J. Morte e vida de grandes cidades. São Paulo: Martins Fontes, 2000.

LAMOUNIER, M. L. Ferrovias e Mercado de Trabalho no Brasil do Século XIX. São Paulo : Edusp, 2012

LYNCH, K. A imagem da cidade. São Paulo: Martins Fontes, 1997.

PREFEITURA DO MUNICÍPIO DE SÃO PAULO - Secretaria Municipal de Desenvolvimento Urbano. Plano Diretor Estratégico do Município de São Paulo. Disponível em: https://gestaourbana.prefeitura.sp.gov.br/arquivos/PDE lei final aprovada/TEXTO/2014-07-31\%20\%20LEI\%2016050\%20-\%20PLANO\%20DIRETOR\%20ESTRAT\%C3\%89GICO.pdf Acessado em outubro de 2018.

PREFEITURA DO MUNICÍPIO DE SÃO PAULO - Secretaria Municipal de Desenvolvimento Urbano. Lei de Parcelamento, Uso e Ocupação do Solo do Município de São Paulo. Disponível em: https://gestaourbana.prefeitura.sp.gov.br/wp-content/uploads/2016/03/PL-272-15-com-raz\%C3\%B5es-de-veto.pdf Acessado em outubro de 2018.

PREFEITURA DO MUNICÍPIO DE SÃO PAULO - Mapa Digital da cidade de São Paulo. GeoSampa. Disponível em: http://geosampa.prefeitura.sp.gov.br/PaginasPublicas/ SBC.aspx Acessado em novembro de 2018.

REIS FILHO, N. G. São Paulo: vila, cidade, metrópole. São Paulo: Via das Artes, 2004.

ROLNIK, R. A cidade e a lei : legislação, política urbana e territórios na cidade de São Paulo. São Paulo: Studio Nobel, Fapesp, 2003.

ROLNIK, R. São Paulo. São Paulo: Publifolha, 2009.

SALES, P.M. R. Operações Urbanas em São Paulo: crítica, plano e projeto. Parte 2. Operação Urbana Faria Lima: relatório de avaliação crítica. Arquitextos, Texto Especial no 300. São Paulo, Portal Vitruvius, 2005. Disponível em : http://www.vitruvius.com.br/revistas/read/arquitextos/05.059/481 Acessado em outubro, 2018

SANTORO, P. F.; BORRELLI, J. Os desafios de produzir habitação de interesse social em São Paulo: da reserva de terra no zoneamento às contrapartidas obtidas a partir do desenvolvimento imobiliário ou das ZEIS à Cota de Solidariedade. In: ENCONTRO NACIONAL DA ANPUR, 16., 2015, Belo Horizonte. Anais do XVI Encontro Nacional da ANPUR. Belo Horizonte: ANPUR, 2015. p. 1-19. Disponível em http://www.academia.edu/12583723/Os desafios de produzir habita\%C3\%A7\%C3\%A30 de interesse social em S\% C3\%A3o Paulo da reserva de terra no zoneamento \%C3\%A0s contrapartidas obtidas a partir do desenvolvimen to imobili\%C3\%A1rio ou das ZEIS \%C3\%A0 Cota de Solidariedade Acessado em outubro de 2018.

SEVERINI, V. F. O novo Plano Diretor Estratégico do Município de São Paulo à luz da Hospitalidade Urbana. In PROJETAR 2015. Anais do VII Seminário PROJETAR Natal, UFRN, 2015. Disponível em http://projedata.grupoprojetar.ufrn.br/dspace/handle/123456789/2040 Acessado em outubro, 2018.

VALENTIM, L.S.O. Requalificação urbana, contaminação do solo e riscos à saúde: um caso na cidade de São Paulo. São Paulo: Annamblume, Fapesp, 2007

\section{NOTAS}

1 Segundo Rolnik (2009, p. 16), "O primeiro grande surto europeu a chegar, em fins do século 19, foi italiano: entre 1888 e 1900 passaram por São Paulo quase 900 mil imigrantes, dos quais 70\% eram provenientes da Itália. Nas duas décadas seguintes, outros 900 mil europeus passaram pela capital, distribuindo-se quase igualmente entre portugueses, espanhóis e italianos". Ainda segundo a autora, entre 1908 e 1930 se instalaram em São Paulo cerca de 50 mil sírios e libaneses e 35 mil judeus.

${ }^{2}$ Os rios Tamanduateí, Tietê e Pinheiros, antes das respectivas retificações, circundavam a cidade por meio de percursos lentos e sinuosos, construindo planícies de inundação, ou "áreas de várzea". As ferrovias foram implementadas nos limites externos das áreas de inundação. 
${ }^{3}$ Segundo Valentim (2007), o crescimento populacional em 10 anos foi de 268\%, passando de cerca de 64.934 habitantes em 1890 para 239.820 em 1900. Em 1930, segundo Rolnik (2009), a cidade de São Paulo já tinha 1 (um) milhão de habitantes.

${ }^{4}$ Coeficiente de aproveitamento (CA), Taxa de ocupação (TO), Gabarito de altura (GAB), Recuos mínimos (REC), Cota-parte máxima de terreno por unidade (CP), Taxa de permeabilidade (TP) e Quota ambiental (QA).

${ }^{5}$ Quadro 3 da LPUOS: https://gestaourbana.prefeitura.sp.gov.br/wp-content/uploads/2016/03/005-QUADRO 3 FINAL.pdf

${ }^{6}$ As ZEIS propostas são: ZEIS 1 - áreas ocupadas por população de baixa renda, onde há interesse regularizar; ZEIS 2 - áreas vazias, subutilizadas ou não edificadas destinadas para produção de HIS; ZEIS 3 - áreas que concentram edifícios, glebas ou lotes não utilizados ou subutilizados, bem localizados, imóveis encortiçados, em áreas centrais, e com boa oferta de infraestrutura e equipamentos; ZEIS 4 - áreas vazias, subutilizadas ou não edificadas em Áreas de Proteção de Mananciais, sobre as quais incidem normas estaduais específicas; ZEIS 5 - áreas vazias, subutilizadas ou não edificadas destinadas para produção de Empreendimentos de HIS e Empreendimentos de Habitação do Mercado Popular - EHMP.

${ }^{7}$ Quadro 2B da LPUOS: https://gestaourbana.prefeitura.sp.gov.br/wp-content/uploads/2016/03/004-QUADRO 2B FINAL.pdf

${ }^{8}$ Quadro 3A da LPUOS: https://gestaourbana.prefeitura.sp.gov.br/wp-content/uploads/2016/03/006-QUADRO 3A FINAL.pdf

${ }^{9}$ A possibilidade de construir mais do que o limite estabelecido pelo coeficiente básico de cada zona de uso, ou seja, pelo coeficiente máximo, pode ocorrer mediante uma taxa denominada "Outorga Onerosa do Direito de Construir". Já os CEPAC (Certificados de Potencial Adicional de Construção) são valores mobiliários emitidos pela Prefeitura do Município de São Paulo, por meio da SPUrbanismo, utilizados como meio de pagamento ao equivalente à Outorga Onerosa, porém dentro do perímetro de uma Operação Urbana Consorciada.

NOTA DO EDITOR (*) O conteúdo do artigo e as imagens nele publicadas são de responsabilidade do(s) autor(es). 